\title{
The Banyamulenge of the Democratic Republic of Congo: A cultural community in the making
}

\author{
S L Rukundwa (Democratic Republic of Congo) ${ }^{1}$ \\ Department of New Testament Studies \\ University of Pretoria
}

\begin{abstract}
In recent years the name Banyamulenge has become associated with a warrior group in Eastern Congo because of the role some of its community members played in the war against the Mobutu regime. Researchers have been intrigued by the political motivations which unfortunately do not cover the cultural aspects of this community. This article attempts to document the cultural heritage of the Banyamulenge community. Many of the practices and traditions have become obsolete. The article explains the Banyamulenge cultural way of living, and how the divine was traditionally revealed to them in the form of human deities. Burnt sacrifice was part of community worship. The article documents what has been learnt from elders about the oral tradition, the cultural and religious realities of the community.
\end{abstract}

\section{INTRODUCTION}

The Banyamulenge people are mainly Tutsis of Rwandan and Burundian origins (see Mutambo, 1997:41; Johnstone \& Mandryk 2001:197), but the community also integrated other Congolese tribes, not necessarily of Tutsi origin. Contemporary researched writings that touched on the Banyamulenge (Weis 1958; Muzuri 1983; Kidogi 1985; Gatimbirizo 1988; Rwigamba 1982; Dupont et al 1996; Mutambo 1997; William 1997; Malengana 2001;

\footnotetext{
${ }^{1}$ This article is based on research done for the MA degree in theology, entitled "The Banyamulen-ge Community seen from social and Biblical perspective, under the supervision of Prof Dr P A Geyser". The degree was conferred by the University of Pretoria (2003). This article should be read in conjunction with a second one, "The Banyamulenge people: Their angst, honor and shame in the light of the Matthean Community", published in the same Number of HTS 60(1\&2). Rev Sebi L Rukundwa is a PhD student in the Department of New Testament Studies at the Faculty of Theology, University of Pretoria, under supervision of Prof Dr Andries G van Aarde.
} 
Ruhimbika 2001), to name but a few, have been mainly directed towards a socio-political and historical classification of their identity in the Democratic Republic of Congo (DRC) and in the Great Lakes Region's context. Most of the research and writings are somehow in reaction to a political issue which has not yet been given proper attention.

The Banyamulenge issue had been orchestrated by tensions and struggles that became an integral part of their history. One of the reasons for their conflict is based on their national identity in the former Zaire (DRC). It was during the recent war of 1996, when the late President Kabila was fighting against the late President Mobutu's regime, that the Banyamulenge community really appeared on the international scene.

What is however often forgotten is that the Banyamulenge people are a people with a cultural heritage and values that provide the background to any venture in or about this community. A second reality is that as with any culture going through a process of change, it is quite apparent that there is a generation gap which needs to be bridged. Younger generations no longer have the opportunity to learn about their own history. They are thus treated in their own land as people without historical and cultural values.

The present generation seems to have lost touch with their cultural roots .... Many young people do not have enough information on their cultural traditions, [and] although no one would like to go backward, there is need of being informed of what is one's past. Therefore, revisiting the old culture is not a matter of leisure but a matter of preserving history, which constitutes the human identity.

(Rukundwa 2003:2)

Since most of the cultural information is still an oral tradition, for the purpose of this study extensive interaction took place with Banyamulenge elders from 1999-2002.

\section{HISTORICAL SETTING}

The Banyamulenge people are mainly Tutsis of Rwandan and Burundian origin, (see Mutambo, 1997:41; Johnstone \& Mandryk 2001:197). For many years they were identified as Banyarwanda, or Tutsi of Congo. This however changed dramatically as a result of the political and social realities during the early 70's and the name Banyarwanda was changed to Banyamulenge as this people's sole identity. According to Kidogi (1985) this name (Banyamulenge) 
has a long history, which dates back to the first Rwandan migrations during the $16^{\text {th }}$ century and was used by those who remained in Rwanda.

L'ethnonyme Munyamulenge n'est pas une appellation récente comme certains l'osent croire. Elle date de longtemps. Elle a été donnée pendant la première migration du $16^{\text {ème }}$ siècle par ceux là qui étaient restés sur place au Rwanda pré-colonial (Kidogi 1985:7).

The name Banyamulenge is derived from the word akarenge and uturenge (in its plural form), which mean small mountain(s). In Kinyarwanda, Umurenge means a village (Mutambo 1997:17). People living in hamlets on those mountains were called bene-turenge or abanyaturenge. These villages constituted an area or a location known as imurenge. Those living in such location were called abanyamurenge. ${ }^{2}$

According to historical speculation (between the $17^{\text {th }}$ and early $19^{\text {th }}$ centuries people completely relied on oral tradition (Weis, 1958:16), the Banyamulenge migrated to the plain of Ruzizi and its environs.). For some other authors however, the migration period of Banyarwanda to the Ruzizi valley varies from the $16^{\text {th }}$ to the $19^{\text {th }}$ centuries (Dupont et al 1996:9). For the Rwandan historian Kagame (1972), quoted by Mutambo, this migration took place around 1576 and 1609 (Mutambo 1997:21).

According to Mutambo (1997:18-23) these different migrations are linked to specific reasons: search of green pastures for their livestock; kingdom conflicts during the reign of Ruganzu II Ndoli between 1510-1543 and famine under the reign of Yuhi IV Gahindiro around 1746-1802. It has to be understood that those periods are however mere speculation. To summarise though, all migrations took place before the arrival (in the region) of western exploration (1857-1858) and well before the partition of the African continent in 1885.

\section{GEOGRAPHICAL SETTING}

The Banyamulenge people live in South Kivu Province, in the eastern DRC. Other tribes that inhabit the province inter alia include the Babembe, Bavira, Bafuliru, Banyindu, Barega, Batembo, Bahavu, Bashi, Babuyu, Banyindu, Barundi, Babangubangu, Babwari, Banyamulenge, et cetera. The Banyamulenge mainly live in the Minembwe, Fizi and Uvira Territories in the southwest of the Province. According to Muzuri (1983), Kidogi (1985), the Kakamba locality was the Banyamulenge's first settlement in the Ruzizi valley and from there they scattered to many other places.

\footnotetext{
${ }^{2}$ Due to different migrations and contacts with other tribal groups, the Banyamulenge community became an integration of Tutsi families from Rwanda, Burundi, Tanzania, and from other Congolese tribes (see Mutambo 1997:41).
} 


\section{CULTURAL HERITAGE}

\subsection{Definition}

From an anthropological view, culture and religion are two distinct terms which however complement each other in giving meaning to a given society. From the African experience there is no culture without religion and there is no religion without a culture. "Historically, religion is one of the institutions every society has perpetuated in an attempt to work out the meaning of existence" (Henderson 1989:50). According to Mbiti (1990:1), Africans "are notoriously religious, and each people has its own religion system with a set of beliefs and practices." According to Malina culture is defined as "an organized system of symbols by which persons, things, and events are endowed with rather specific and socially shared meanings and values" (Malina 1993a:9). It is made of those shared attitudes and values in any given society. In addition to that, culture "is a design for life. It is a plan according to which society adapts itself to its physical, social and ideational environment" (Luzbetak 1963:6061). Therefore, culture is a way of life of a community. It includes language, customs, values and common goals for survival.

Religion isdifficult to define, especially from an African perspective. According to Mbiti "religion can be discerned in terms of beliefs, ceremonies, rituals ...." He continues to argue that religion "is the strongest element in traditional background, and exerts probably the strongest influence upon the thinking and living of the people concerned" (Mbiti 1990:1). Religion can also be defined as beliefs in spirits and supernatural beings.

\subsection{Culture (umuco)}

\subsubsection{Habitation, economy and taboos}

The Banyamulenge live in hamlets in areas that are suited to their livestock. Until the late 70's, they were semi-nomadic. Their movement depended on the health of families and their livestock. Death and poverty were linked to a place (ikibanza), and every responsible head of a family has a duty to protect his family and properties by changing the place of habitation. Villages or hamlets generally were built according to clans and family affiliation.

Until the 1960's, livestock (cows, sheep and goats) was the Banyamulenge's main economic source/livelihood Poultry (chicken: inkoko) was used in smaller economic activities, such as sales or in exchange for a service rendered by a neighbour or to build relationships (ubgira) with neighbours. The Banyamulenge considered it as shameful to eat chicken. To this day Pork (ingurube) is regarded as an unclean animal, not to be kept by 
any members of the community. Goat (ihene) could be sold or exchanged for whatever was needed in the family, but was only to be eaten by men as it constituted a taboo for women. Traditionally, sheep (intama) was considered as a peaceful and sacred animal.

A cow (inka) was considered as something next to man. Apart from its milk (amata) and meat (inyama) as the community's.staple food, and butter (amavuta), its horns (amahembe) were used as water containers; its skin (uruhu) for clothing and mats; its urine (amaganga) as a disinfectant; the cowmanure (amase) was used to roughcast houses (guhoma) and as fertilizer (igitebo). The cow served as dowry (inkwano) and as economic source for the family. Finally, the cow was and still is regarded not merely as an animal, but is called imbyeyi or mwimanyi (benefactor). In this regard Kidogi points out: à ce sujet une vache laitière est appelée 'imbyeyi' ou bien on pouvait encore l'appeler 'mwimanyi' c'est-à-dire bienfaitrice (Kidogi 1985:24)

For ages, the community lived on milk (amata), cooked blood (ikiremve) and cow's meat only. But due to contact with other cultures, the Banyamulenge started cultivating and eating other forms of food. Fish, pork, chicken and all wild animals were considered unclean and would thus not be eaten by anyone in the community.

Their main vessels were: containers made of wood (inkongoro) for milk in different categories; and a big calabash (igisabo) for making butter (amavuta), imbehe (a wooden plate) and inkono (cooking pot), which came from their neighbours.

\subsubsection{Clothing}

Traditionally adults wore calf skins, and children goat and sheep skins. Women also wore jewels for beautification: on their necks, hips and legs, they wore bracelets, known as inyerere ibitare and inigi. A bracelet, known as the urugoro was worn on their arms for men. Married and unmarried people were distinguished by the way they dressed. Women wore skirts of cow skins (inkanda), while young boys and girls wore the soft skins of calves and goats. Men wore cows' skins and the style was called urubega.

Each social group had its own particular haircut. Mens' heads were shaven but for a line left from the front to the neck (isunzu); in the case of women all hair was shaven off (agakumbu), while in the case of the boys and girls, some hair was to remain on top of the head, also known as isunzu. Unmarried and married members of the community could be distinguished by their clothing or by their haircut. For a long time a special skin lotion, prepared from butter and mixed with special tree leaves for fragrance in a container, called icwende, was used as a fragrance. 


\subsubsection{Poetry, song and dance}

The men and women of the community were talented in song (indirimbo), dance (imbyino) and poetry (ibyivugo or ibironda). Unfortunately, these traditions were only passed on by means of oral tradition and are not otherwise recorded. Songs used to be philosophical and psychological in nature. They were used in praise of both men and women whose social achievements were recognised, as well as being composed for cows and for special occasions.

The traditional dances of the Banyamulenge used to be known as Gutamba (slow style), kubyina izinka (an energetic style), and Imbarato. ${ }^{3}$ These dances were performed at all special occasions and festivities, such as marriage, sacrifice, cultural initiation, and the usual dancing occasions, called ibitaramo. The ibisabo (big calabash), imyirongi (flutes), and inanga (harps) were used as music instruments. One of the traditional songs goes like this: $\mathrm{Ni}$ Rugerera rwasimbye urugabane itaha yigaza murugamba. Nanje nkumbuye Rumaranzara, inka yandemesheje mu Rugarama. In this song, the singer is singing in praise of his cow that has taken away his shame and hunger and has cared for him in Rugarama (a village where he lived).

\subsubsection{Social and family classifications}

A sense of belonging to a reputable and well known family was considered as prestigious. Records had to be traced generations back and established the status of grandfathers or great-grandfathers. The spirit of genealogy is still strong in the community's keeping of ties with family roots.

The society is built on family, clan and community (see Bourgeois 1954:112; cf Mutambo 1997:132-133). For example, Rukundwa belongs to the family of Rugayampunzi in the clan of Abitira, which is part of the Banyamulenge community. On the other hand, socialisation depended on age and sex group. Community leaders were classified according to their wealth: number of heads of cattle one possessed and the size of the family (children and other family members) he belonged to. The bigger the family, the wealthier an individual was considered to be. As a consequence polygamy was a frequent occurrence and was accepted as a sign of wealth. Leaders in the society were those on family, clans and location levels.

The first-born boy in a family was the immediate heir of his father's responsibility and was expected to look after the rest of the household when the father died. In the event of a girl being the first born she was not to be called as such and did not inherit her father's responsibility. The culture

\footnotetext{
${ }^{3}$ Imbarato or Cihariza is another type of dance taken over from their Bafuliru neighbours, and its main song was called ntamakemwa. It originated in 1956-57 during a mass decrease of the influence of Christians (see Rukundwa 2003: 35).
} 
regarded her as a "passenger" who was born for others, that is, she would marry and leave her father's family. For this reason, even if he is the last born among many sisters in a family, would still be regarded as the first-born. In the case of the first-born boy inheriting the father's responsibilities after the latter's death, he (the son) would be given a spear by a council of elders as a sign of full replacement of his late father. Elders of the family would help him (the heir) to reach a higher status and to be more effective as he replaced his father, not only in the immediate family, but also in the community.

Elders of each family, clan, village and location formed a council of elders, which dealt with all matters arising in the society and this council was respected by all. Poor people and women in general did not have much say in society and were dependent on the decisions of the rich. Poverty was defined in terms of lack of children and the number of head of cattle. The imfura (men of integrity and compassion) was another category of men in the society. The Imfura could come from both the high or middle class, and cared for the poor and showed generosity to the community. This title or achievement was also given to women of integrity (imfurakazi).

There was also a tradition of exchanging information (kwibgirana amakuru). When two strangers met along the way, they would stop and introduce themselves as a way of unity, solidarity and communication. In this way, an exchange of information occurred between different places. During the course of a journey this exchange would take place with as many people as one would encounter on his way. Upon his return, the entire village would come to greet the journeyman and to enquire about the trip (kubaz'amakuru). His account would start with the day he left his home and would give every detail of his journey. This account was called mpuruyaha.

Education was informal. Tales of old people in villages, gatherings, ceremonies and festivals were part of the learning system. Different procedures were followed for the initiation of boys and girls. Boys were taught to be brave against enemies and wild animals. Fear was associated with feminism (Rukundwa 2003:18-19). Different values were instilled in girls they grew up with the prejudice that they were inferior to boys. From an early age they were taught how to do domestic work, such as collection of firewood (gutoragura), cleaning the dens of the cows and calves (gukuka and kwahir'iricarire c'inyana), assisting men when milking (gukamisha), fetching water (kuvoma) and cooking (guteka). They were taught songs and dance. Their early marriage depended on how strong and efficient they were rated in the execution of their domestic activities (ubukuba), or by the wealth of their parents. Virginity of a girl was very central.Girls were taught how to keep themselves pure so as not to destroy their lives. 


\subsubsection{Marriage}

\subsubsection{Dowry payment procedure}

Marriage in the Banyamulenge community was unique and kept the community from tribal inter-marriage. Marriage could be between two families belonging to two different clans. Marriages between cousins from the mother's side were permitted. This was also true of Burundians and Rwandans (see Bourgeois 1954:123). Dowry could not be paid in any form other than cows. Other tribes could pay dowry in the form of goats, money, hoes, clothes, et cetera. The number of cows to make up the dowry depended on how rich one was. Social classes played a role. Poor went to married into poor families and rich into rich families. It is important to note that a groom could not choose his bride. That was arranged by the parents and families. In some cases, the couple (groom and bride) met for the first time on the day of the marriage. The marriage ceremony had several stages to it:

- Introduction (kubaz'umugeni) or fiançailles

- $\quad$ Payment of dowry in instalments (inka yo gufat'irembo). This period could stretch over many months or even years.

- $\quad$ Payment of dowry in full (gukoshanya).

This stage involves a whole process. Up to this stage (ie before marriage?), a groom had no property (cows) of his own. Therefore his family paid the dowry (inkwano) for him/on his behalf. The bigger number his parents paid, the more (indongoranyo) the groom (and the bride) would have to start their family life with (see Bourgeois 1954:141-143). Part of the dowry paid (gukura izigitwe) remained with the bride's family and the rest would be given to the new family. For instance, if the groom's family paid twenty cows, the bride's family would remain with seven or ten, and would give the rest to the groom as the foundation of their future family. But poor families paid only few cows one or two. These cows were called inyegeka, because the groom would not get indongoranyo.

\subsubsection{Preparation of the bride coming home to the groom}

Three options were used in preparation of the bride entering the groom's family:

- $\quad$ The groom could first of all go to the bride's family to stay with his fiancée and her family for between 12 to 24 months. This was called gutahira. The groom thus familiarised himself with his family-in-law. 
After that period, he would go back to his home and his family arranged the marriage ceremony.

- $\quad$ The groom's family could choose for $t$ the bride to directly come to the family without gutahira.

- $\quad$ The groom could be motivated by his peers to take his bride by force (guterura) and bring her home. A messenger would be sent to the bride's family to inform them about the happenings. The message was called kwibura (to ask for forgiveness for the act committed).

Whatever the option exercised, each ceremony was characterised by a particular speech (gufomora) along with local brew (inzoga). Marriage ceremonies used to be held at night, and were characterised by drinking, eating, singing and dancing. The bride and the groom would exchange big calabashes (ibisabo) and both would go around a burning fire (igicaniro) before entering their house. Igisabo and igicaniro symbolised blessing and wealth. On the day of the marriage ceremony two important things were done: The first involved the use of milk (as the equivalent of modern wedding rings). The groom and the bride would hold milk in their mouths and spit it on each other's legs as a sign of a clean marriage and to claim their commitment to each other. This was called gucir'an'imbazi. The second ritual was that before the couple would sleep together, two other young people of their age (a young man and young lady) would come and sleep with them on the same bed for a while before taking their leave. This was called guter'umwishwa.

The bride would not be seen in public as she would remain in the house in a place called mugakinga for one to two weeks, until her father-inlaw would come and greet her (gutinyura). He would use words such as "this family is yours, make it your own, organise it, defend it and multiply it. You are no longer a stranger, its people are your people and its wealth is yours as well." This event would be followed by a visit from her own family, coming to greet her (gukoza muziko). After six months, the wife would go to her parents to greet them and stay there for one month (kuramutsa). During this period, she would still be called umugeni and would spend time in the company of her sisters-in-law (baramukazi), wives of her brothers-in-law (bakeba) and from time to time her mother-in-law and grandmother of her husband. They would teach her the internal affairs (what to do and what not to do) of their family. As a way of expressing respect the bride was not supposed to call her parents-inlaw and those related by their names (gutsinda).

Lastly, after she had settled in her own life, she would be allowed to return to her parents for six or twelve months to greet them. Upon her return, she would be escorted by many people and would bring kitchen utensils and 
food along and would from now on have her own kitchen (guteka). During this time, the husband would also have changed camps and peer group. He would now identify with the married ones where he would be instructed into family responsibilities.

Marriage was not a private business of a man and a woman, but a business of families. The wife who came into the family, became the wife of the family; she became part of the family. According to the customs, peers from the same family could exchange wives for sexual intercourse, and the children thus born, still belonged to the family. The identity was in the extended family, rather than in the immediate one. This way of life enabled impotent men and widows to have children born to them. Adultery was an offence if committed outside the family of involved partners. And it was a serious offence if committed outside tribal boundaries. This resulted in immediate divorce or the woman had to undergo some cleansing rituals and would be given fines (iciru) before she could again have sexual intercourse with her husband.

Separation (kwahukana) and divorce (gutandukana burundu) were not frequent, but were allowed under certain circumstances:

- $\quad$ Adultery (with men outside the family)

- $\quad$ Laziness

- $\quad$ Stubbornness of either of partners

- Barrenness

\section{RELIGION}

\subsection{God "Imana"}

Through generations, "New events (bad or good), such as conflicts, wars, education, modern civilization, cultural interference, do affect existing cultural norms in any given community. But traditional religion does not know reform, one has to stick with it or fall out of it" (Rukundwa 2003:12).

"Religion in African societies is written not on paper but in people's hearts, minds, oral history, rituals ..." (Mbiti 1990:3). The term Imana (God) is used to refer to a Supreme Being, unreachable and beyond other gods. He is the creator of all things (Bourgeois 1956:11). Imana was only invoked when all other earthly, spiritual possibilities and other alternatives had failed to save a situation. People would then use the expression ahasigaye n'ah'Imana, which means "it depends on God's intervention or only God knows". He allowed blessing and prosperity in the community, while Nyabihori (the devil) was the creator of the evil and inflicted poverty on people. 
In one of the women's songs, they sing about Imana: icompa nkamenya aho irara nkayipfukamira nkayisenge, nkayibaza ico yahoye umutindi (May I know where he lives and I would go to worship him and ask him why he created the poor). Moreover, Imana was an expression to impossibilities ${ }^{4}$.

\subsection{Worship and high priests}

The Banyamulenge, like their neighbours, had gods. Their main god was known as Ryangombe. Ryangombe was also the god of the Banyarwanda (see Bourgeois 1956:10-12) and the Bashi. For the Banyamulenge, Ryangombe was in the form of a woman. There was also another agent of god, known as Binego or Mushayija, in the form of a man. This god was tough, had nothing to offer and was feared by the people Binego referred to himself as "Ndi Mushaija, ndi rukenya-bugingo rwanjanja, ndabyarwa si mbyara" (I am the destroyer of life, I am born and cannot give birth).

Ryangombe was worshiped while sitting on a chair, holding a cooking stick (umwoko). She was the god of blessing and procreation. Every time of worship, offerings were given. This could be an offering of thanksgiving, praise, a pledge or of forgiveness. The worshippers would say: kajikera Ryangombe, uramp'ibyara n'itinga (live long Ryangombo, may you give me many children as well as wealth). At the same time, worshippers asked for protection. Only those who had gone through religious initiation (kubandwa), could play the high priesthood role in the form of Ryangombe and Binego. It must also be noted that the Banyamulenge never worshipped objects and nature.

There used to be four ways of offering sacrifice and worship (rituals):

- Worship of spirits of ancestors (imuzimu ya basogokuru): the family would build a small house or use a piece of prepared ground to which they would bring fire, milk and/or drinks (local brew). They would pray to the spirits (communication between the living and the dead). They believed that ancestors never disappeared and still had power and an important role to play in the daily lives of the living.

- $\quad$ Kumurika. A female lamb (blameless), fire and milk were taken to a prepared place (altar) and the head of the family would confess all their needs onto that lamb called intama y'icogoro. This process was called kumurika. The lamb was presented as an offering of the family to their god and was not supposed to be killed. This process was known as

\footnotetext{
${ }^{4}$ Imana was able to repair the unrepairable, hence the expression ahasigaye nah' Imana ...." (only God knows ...) is still used today.
} 
kumurika. A calf, known as inka ya kagoro, was sometimes used in stead of the lamb.

- Kubandwa. This was an initiation of persons into the group of priests (imandwa). This group was made up of men and women who held the secret (ibanga) of spirits. On that day, they painted their faces with white soil (ingwa) and would act in a wild manner and would utter shameful things. This ceremony would last one or two days.

- $\quad$ Guterekera. In case of any problem or difficulty in the family, the head of that family would go to a traditional healer (umupfumu) or a seer (umuragu) to find out why his family or livestock was in trouble. This process was called kuraguza. The healer would advise that his ancestors' spirits were haunting him for one of the following reasons: either he had not been true to his pledges during previous difficulties or he had neglected communicating with the gods or offering a sacrifice. The person would then plan a sacrifice ceremony, known as the guterekera.

Guterekera was the most expensive and sacred ceremony. The family concerned would prepare a beautiful and blameless ox, which would be first checked to make sure it had no blemish (agasembga) before it could be offered. A selected man would be given an axe to kill the ox, if he cut twice, or the ox groaned, then it was not worthy of sacrifice (gupfuba), and another ox would be selected. The ritual was to cut once and no noises should be heard. The family would prepare vast quantities of drinks and milk; others in the village and its surroundings would also be invited and would even make contributions towards the ceremony. The ceremony would last two to three days. The family would invite priests (imandwa), relatives and friends as well.

Come worship time, the Ryangombe and Binego would sit together on chairs outside, the head of the family would present all his needs, whereafter the gods would accept the sacrifice and grant his requests. The rest of the congregation was also free to worship and present their needs. As a sign of worship and their commitment, the congregation went through the process of icuhagiro: they would use white mixed mud (ingwa) and the leaves of a special tree, called umuko, mixed in a big pot, to paint everyone worshipping there. The painting was called ikirabo. A pot filled with local brew (inzoga) or a container (inkongoro) filled with milk (amata) was also available. The high priests would drink form these, hold the contents in their mouth and spit it onto (gufuhira) all those who were present as a sign of blessing and prosperity.

In an open place in front of the house of an initiated family, there would be a burning fire called igicaniro (altar) which was considered as sacred. On 
the day of the sacrifice, they would take all the bones (amagufwa), abdomen (amayezi), horns (amahembe) and blood (amaraso) of the sacrificial ox and burn it. As the smoke rises and spirals, they believed that their prayers were heard! "It is enough to know that religion was part of cultural process and worship was never done individually or secretly: gods belonged to the community and should only be worshipped through and by the community" (Rukundwa 2003:26).

\section{POLITICAL IDENTITY}

The relationship between the Banyamulenge and their neighbours was generally good. All tribes had developed a system of economic exchange and good neighbourliness. The Banyamulenge were cattle keepers, while their neighbours lived on cultivating the land and on hunting. The Banyamulenge provided them with cows, milk and meat. In turn, their neighbours provided them with other forms of food: cassava, banana, maize, beans, and this exchange developed into proper economic ties and friendship (ubgira) with the person offering the goods being called umwira (a friend). Bafuliru and Bavira would bring goods (food or salt for cows) to their Banyamulenge friends and this operation was called gushegura (see Gatimbirizo 1988:22). In turn, the Banyamulenge would give them cows, meat, milk, butter, sheep, goats and chicken.

Moreover, members of different tribes, mainly the Bavira, the Bafuliru and the Banyamulenge had strong relationships, to the extent of making blood pacts, known as kunywana igihango. Therefore, families involved in this process became one family and one blood. And so, no one could harm or even be in conflict with each other. However, in the event of domestic or local conflicts arising between Banyamulenge and their immediate neighbours, elders from the conflicting communities would sit together and settle issues as they shared a drink (inzoga). Fines were charged according to the weight of the offence. This would also be followed when two members of the same community had differences.

The Banyamulenge was known as the Banyarwanda of Congo (Biebuyck 1973:3; see Malengana 2001:132) or the Congolese Tutsi by their neighbours. This name did not bother the Banyamulenge until it became exploited and abused by politics of exclusion and confusion right from colonialism to the post-independence period (cf Gatimbirizo 1988: 25). According to the history, the Banyamulenge had been part of the local administrative entities before and during the colonial period (Kidogi 1985:16). According to Gatimbirizo, dans l'administration coloniale, c'est le décret du 6 octobre 1891 qui pour la première fois tenta une réglementation des institutions administratives. Certaines chefferies furent reconnues .... In a decree of 6 October 1891 two chieftains in the Uvira Territory, belonging to 
Kayira and Gahutu, both Banyamulenge chiefs, were officially recognised by the colonial administration..(Gatimbirizo, 1988:26).

According to Kidogi (1985:22-32), the Banyamulenge strongly resisted the colonialist idea of land occupation, because of the survival of their livestock. Secondly, they were resistant to be treated as colonial subjects. However, the Banyamulenge became the first victims and the most seriously affected of the colonial politics of divide and rule. This resulted in the suppression of traditional administrative structures (Mutambo 1997:65-67), which by 1933 left the Banyamulenge without any traditional identity and without control of any land they could call their own. "Compte tenu de manque de soumission des Banyamulenge à l'égard du colonisateur, un processus de déstabilisation de ce peuple pasteur fut amorcé (Kidogi 1985:32). Indeed, as Young says, colonialists had taken from African people the history [and cultural values] that had hitherto been theirs (Young 2001:288).

Consequently, the Banyamulenge people were administratively represented by their neighbours (the Bafuliru, Bavira and/or Babembe). They were regarded as mere outsiders from Rwanda and Burundi (see Muzuri 1983:140). According to Mbonyinkebe (no date 1-9) the Banyamulenge people were victims of the Belgian colony in a number of ways: the Banyamulenge were seen as potential competitors in livestock and they resisted colonial compulsory measures imposed on agriculture.

\section{SUMMARY}

As much as the culture is static, each generation must pass onto the next some of the values that make a people unique as a community. The Banyamulenge people do not only belong to a big Tutsi family, but they also have a culture that creates their identity in time and space. Their cultural values with regard to habitation, marriage, social classification and religion, are worth studying. It is also noted that in their religious worship, they never made reference to objects or nature. Their sense of identifying god in the form of human beings (Ryangombe and Binego) is of particular interest. This belief provides an interesting analogy to the introduction of the human-God in the Gospels.

Political realities affected their ways of life in many ways. Their insubordination to colonialism endangered not only their relationship with colonial masters, but also with post-colonialism regimes. There is every indication though that their relationship with their neighbours was good, until it was strained by the politics of divide and rule.

\section{Works consulted}

Biebuyck, D 1973. Lega culture: Art, initiation, and moral philosophy among Central African people. Berkeley, CA: University of California Press. 
Bourgeois, R 1954. Banyarwanda et Barundi: La coutume. Bruxelles: Institut Royal Colonial Belge.

Bourgeois, R 1956. Banyarwanda et Barundi: Religion et Magie. Bruxelles: Institut Royal Colonial Belge.

Dupont, A P et al 1996. Conflits au Kivu: Antécédents et enjeux. Anvers: Université d'Anvers.

Gatimbirizo, N 1988. Problématique de la participation du Munyamulenge à la gestion des entités politico-administratives locales: Etudes de cas dans les Hauts-Plateaux d'Itombwe (Sud-Kivu). Unpublished mémoire de licence en sciences politiques et administratives, Université de Lubumbashi.

Henderson, G 1989. A practitioner's guide to understanding indigenous and foreign cultures. Springfield: Charles C Thomas Publisher.

Jonstone, P \& Mandryk, J 2001. Operation world. $21^{\text {st }}$ ed. Carlisle: Paternoster Publishing.

Kagame, A 1972. Un abrégé de l'ethno-histoire du Rwanda. Butare: Editions Universitaires du Rwanda.

Kidogi, W 1985. Colonisation belge face aux structures socio-politques et economiques traditionnelles africaines: Cas des Banyamulenge au Sud-Kivu de 1908-1960. Unpublished monographie de graduat en histoire et sciences sociales, IPN.

Luzbetak, L 1963. The church and cultures: An applied anthropology for the religious worker. Techny: Divine Word Publication.

Malengana, C N 2001. Nationalité et citoyenneté au Congo/Kinshasa, le cas du Kivu. Paris: Harmattan.

Malina B J 1993. The New Testament world: Insights from cultural anthropology (rev ed) Louisville, KY: Westminster John Knox Press.

Markowitz, M D 1973. Cross and sword: The political role of the Christian missions in the Belgian Congo, 1908-1960. Stanford: Hoover Institution Publications.

Mbonyinkebe, S D s a. Les conflits inter-ethiniques dans leur contexte historique et Socio-anthropologique: Le cas des populations de l'Itombwe au Sud - Kivu (Zaire). Unpublished paper, Université de Kinshasa.

Mutambo, J J 1997. Les Banyamulenge: Qui sont-ils? D'où viennent-ils? Quel rôle ont-ils joué (et pourquoi) dans le processus de la libération du Zaïre? Kinshasa: Imprimerie Saint Paul.

Muzuri, G 1983. Evolution des conflits éthniques dans l'Itombwe, Sud-Kivu, des origines à l'an 1982. Unpublished mémoire de licence, Université de Lubumbashi.

Ruhimbika, M 2001. Les Banyamulenge (Congo-Zaire) entre deux guerres. Paris: Harmattan.

Rukundwa, S L 2003. The Banyamulenge community seen from social and biblical perspective. Unpublished MA thesis, University of Pretoria.

Young, R C J 2001. Postocolonialism: An historical introduction. Oxford: Blackwell Publishers.

Weis, G 1958. Le pays d'Uvira, étude de géographie régionale sur la bordure occidentale du lac Tanganyinka. Bruxelles: ARSC.

William, J-C 1997. Les Banyarwanda et les Banyamulenge. Paris: Harmattan. 